\title{
Root Stability Evaluation with Non-Destructive Techniques
}

\author{
Ágnes Kinga BuZA ${ }^{a^{*}}-$ Ferenc Divós ${ }^{\mathrm{b}}$ \\ a József Bódig Non-destructive Testing Laboratory, University of West Hungary, Sopron, Hungary \\ ${ }^{\mathrm{b}}$ Institute of Physics, University of West Hungary, Sopron, Hungary
}

\begin{abstract}
Due to their huge benefits when compared to invasive or destructive techniques, the use of non-destructive approaches is continuously increasing in many fields. The visual assessment method is commonly applied in tree inspection, but it has limitations. Investigations using appropriate nondestructive instruments can well complement visual tree inspection. This paper is a short overview that describes non-destructive techniques for evaluating the load-bearing capacity of individual trees' root systems. The techniques used are acoustic root detection and the pulling test. Safety factors were also calculated to provide a hazard assessment.
\end{abstract}

root detection / pulling test / acoustic root detection / safety factor / non-destructive evaluation

Kivonat - A gyökérzet biztonságosságnak becslése roncsolásmentes vizsgálati technikákkal. A roncsolásmentes megközelítés számos területen terjed folyamatosan a roncsolásos technikákhoz képesti el nyeinek hála. A fák vizuális értékelése elterjedten használt, ám ennek megvannak a maga korlátai. A m szeres vizsgálatok jól kiegészíthetik a vizuális méréseket. Jelen cikk egy összefoglaló, mely a biztonságosság és terhelhet ség irányából közelíti meg a fák gyökérzetének vizsgálhatóságát. A bemutatott roncsolásmentes technikák az akusztikus gyökér érzékelés és a húzóvizsgálat. Emellett a biztonsági faktorok számítása is röviden összefoglalásra kerül.

gyökér érzékelés / akusztikus gyökér keresés / húzóvizsgálat / biztonsági faktor / roncsolásmentes értékelés

\section{INTRODUCTION}

Trees have played a vital role in human life and civilization for thousands of years; their significance in society and industry is undeniable. The many roles trees play within the human sphere makes the examination of tree conditions an especially important task.

The root system is an 'invisible' part of trees that is crucial to both tree metabolism and stability. There are numerous techniques to study the root system - some are invasive and cause harm to the tree, while others are non-destructive and do not harm the tree. Non-destructive methods have the advantage of repeatability - that is they can be employed more than once on the same tree. Long term study of the root system and growth is becoming possible.

Non-destructive evaluation of trees is an area of non-destructive testing (NDT). Nondestructive evaluations are increasingly being recognized as effective methods for examining

*Corresponding author: agnes.kinga.buza@gmail.com; H-9400 SOPRON, Bajcsy-Zs. u. 4. Hungary 
the internal conditions of various materials without disturbing or destroying them. Even though some NDT techniques have already become well-proven in research, it takes time for the technology to be implemented in field.

This paper briefly reviews NDT techniques for root stability evaluations. The aim is to present summarized information to help understand the usage and the limitations of these techniques. An instrumental background is required to quantify the effects of injuries and infections (e.g. fungus), or to quantify the sizes or loss of material in the case of decay and cavities. We believe that NDT methods have their benefits and deserve to have wider utilization.

Non-destructive evaluation techniques have been applied with varying objectives in many fields such as urban trees, forestry, ecology, and horticulture.

The main trends in research focus on:

a) Determining the biomass content of forest, trees or roots and underground biomass content (Morelli et al. 2007; Borden et al. 2014);

b) Evaluating the safety of individual trees including root systems (Brudi - Wassenaer 2002; Wu et al. 2014);

c) Determining tree response to static and the dynamic loads such as wind, snow or rockfalls (Dorren- Berger 2005; James - Kane 2008);

d) Assessing wood quality in standing trees and determining the effect of site conditions, stand age, and silvicultural treatments on wood quality (Wang et al. 2006; Grabianowski et al. 2006; Wang 2013).

Instrumental techniques are diverse according to the aim or/and the use of the measurement.

The major applied non-destructive techniques in root system investigations are pulling tests, ground penetration radar (Guo et al. 2013), and electric resistivity tomography (Amato et al. 2008; Zenone et al. 2008). A comparison of ground penetration radar and pulling tests (Danjon - Reubens 2007) has been reported.

With respect to tree safety, visual assessment has been used to determine the load-bearing capacity of root systems. Several researchers have reported the relationships among the diameter at breast height $(\mathrm{DBH})$, tree height $(\mathrm{H})$ and the stability of roots, anchorage strength, the maximum of force or bending that can be survived without damage. (Some researchers use calculations with standardized, unified force, while in other works bending is the parameter used. If force is applied at different heights, the same force can lead to different bending.)

In many experiments the force, or bending moment, causing uprooting or trunk failure was determined. For instance, Peltola and colleagues (2000) pulled over 95 trees (51 Scots pines (Pinussylvestris L.), 33 Norway spruces (Piceaabies (L.) Karst.), and 11 birches (Betula spp.)) and their analysis showed that the second power of DBH multiplied by tree height $\left(\mathrm{DHB}^{2} \mathrm{H}\right)$ predicted anchorage strength; while the third power of breast height diameter $\left(\mathrm{DHM}^{3}\right)$ best served for forecasting stem failure. Similar results are presented in the work of Lundstrom and colleagues (2007) who collected data on a total of eighty-four trees (including 57 Norway spruces (Piceaabies (L.) Karst.), 23 silver firs (Abiesalba Mill) and other species) and stated that the breast height diameter squared times tree height $\left(\mathrm{DHB}^{2} \mathrm{H}\right)$ is a parameter to forecast root stability. However, Achim and Nicol (2009) found breast height to be an acceptable parameter for predicting anchorage strength.

The instrumental techniques presented in our paper are pulling test and acoustic root mapping; it is possible to predict the root system and stability with both methods. These instrumental methods can also be employed in the evaluation of safety needs calculations on loads (with wind load being the most common) and estimations of the load-bearing capacity of trees. The safety factor is a value quantifying safety to help decide whether a tree should be retained or felled. One way of calculating safety factors is also described in the work of Brudi and Wassenaer (2002). 


\section{PULLING TEST}

The pulling or winching test is a method for investigating the root-soil system and root anchorage. Assessing the safety of trees and evaluating stem conditions are other applications of pulling, as well as serving as calibration for measurements in real wind situations. (The moment caused by winching and the created inclination is measured. In wind or storm conditions, the inclination can be measured and the inducing moment, that is the "strength of the wind," can be evaluated.) Destructive pulling should also be mentioned at this point. With this method, researchers can uproot trees in order to compare different conditions for the bending moment causing failure. Plenty of excellent papers are available on the implementation and the usage of these tests (Bell et al. 1991; Wessolly 1991; Rodgers et al. 1995; Ray - Nicoll 1998; Neild - Wood 1999; Moore 2000; Peltola et al. 2000; Silins et al. 2000; Brudi - Wassenaer 2002; Clair et al. 2003; Lundström et al. 2007A; Lundström et al. 2007B; Kane - Clouston 2008; James - Kane 2008; Sani et al. 2012; Siegert 2013; James et al 2013; Rahardjo et al. 2014).

During a pulling test (Figure 1) a cable is generally placed on the tree as close as possible to the crown center or half of the trunk. The other end of the cable should be anchored to another tree or other object, and the applied force should be measured. During the test, a pulling force is applied through the cable to bend the tree and the inclination, elongation, and dislocation of the ground are monitored and measured. (Elongation is usually measured along the trunk at higher levels as seen in Figure 1. As the stem bends, it elongates as well. Conditions of the trunk can be evaluated. Dislocation of the ground is caused by the roots as they move and/or break during the pulling. Measurements can be performed on the ground near the winched tree.)

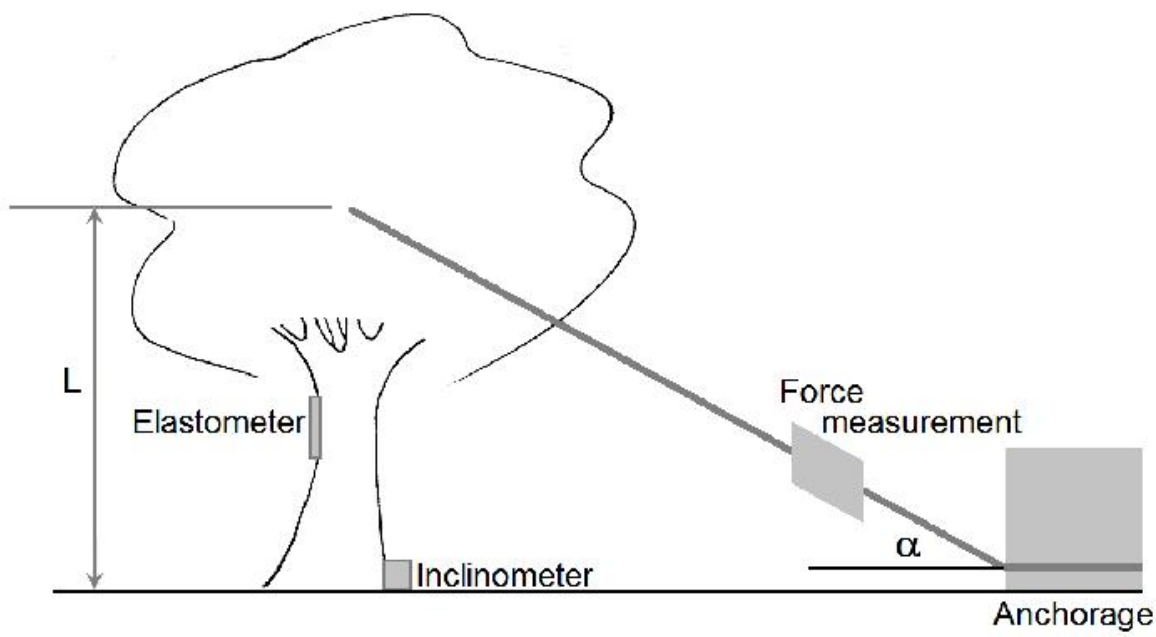

Figure 1. The schematic diagram of a pulling test. The cable should be anchored in a secure object for the test. $L$ is the height of the cable's anchor point at the center of the crown

The inclination of the tree's trunk should be measured if the purpose of the testing is to evaluate the risk of tree uprooting. The inclinometer should be fixed to the trunk at ground level. (At higher levels the trunk's elastic deformations modify the results. A ratchet strap can go around the trunk and fix a flat little "shelf" which folds the inclinometer. If the fastening is tight, the inclinometer moves with the trunk.)

The pulling test usually continues until the inclination of the trunk at ground level reaches 0.020-0.6 degrees. The collected force-inclination data should be filtered according to the relaxation of the tree. (Winching stresses the tree, causing inclination; although relaxation of the wood material of the tree does occur. For the evaluation of safety, only the inclinations immediately responsive to the pulling are used. Inclination data that are collected during the 
relaxation effects should be neglected.) (Divós et al. 2009; Sani et al. 2012; James et al. 2013). The difference between trees can be stated clearly, even for the same species at the same field; the measured pulling moment ranges between 0.07 and 0.6 degrees. The force used and the caused moment were higher for trees whose tilt was 0.07 , which refers to more enormous anchorage strength than trees that tilted 0.6 degrees for weaker winching. (James et al. 2013)

The pulling of a tree should be less than 0.25-0.6 degrees to avoid injuring the roots. (This range is quite great according to the difference of trees.) Coutts (1983) found that the first sound indicating root breaking started at a 0.5 tilt. Rahardjo and colleagues (2014) established a model of tree felling based on their field experiences. They also verified roots breaking during uprooting and stated root cross-sectional area and root plate radius to be relevant for root anchorage evaluations. Modeling focusing on root failure (shape and stresses) was presented by Lundstorm and colleagues (2007B).

Brudi and Wassenaer (2002) reported that irreversible failures usually occur above 2 degrees of inclination. Nearly no additional force is needed to pull a tree over from 2 to 40-60 degrees. Lundstrom et al. (2007B) found that the maximum bending moment is observed between 2-15 degrees. An example of turning out is seen in Figure 2. The maximum tilt reported was 0.9 degrees in wind gusts up to $90 \mathrm{~km} / \mathrm{h}$, while $0.5-0.6$ degrees were declared as average (James et al. 2013).

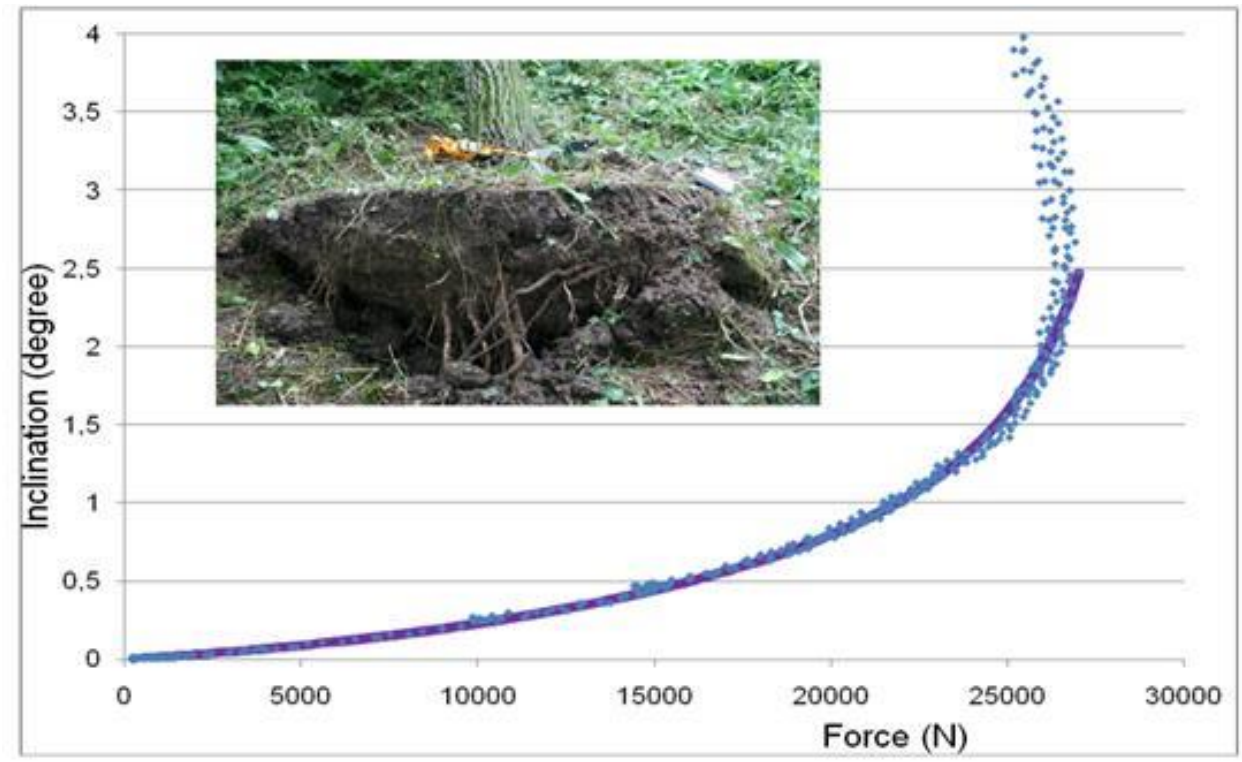

Figure 2. An example of uprooting (shown in the photo) and the pulling test data. (Divós et al. 2009)

After a pulling test, the whole tree should return to its original position. However, a complete recovery from a pulling test can take several minutes (James et al. 2013). Bending of the trunk was studied for Sitka spruce both in the field and with models by Neild and Wood (1999) who found out root flexibility is a non-negligible factor in pulling testing.

Pulling tests can also be performed on trees with buttresses. The stability of the trees was found to be lower for pulling tests conducted on the buttress sides (Clair et al. 2003).

Soil conditions can affect tree stability measured by pulling tests as it is described in the work of Moore (2000) and Bergeron and colleagues (2009).

Temperature conditions, particularly frozen soil and frozen trunks, will affect pulling testing. For instance, Silins and colleagues (2000) performed the pulling test to determine strength in frozen and unfrozen conditions. Peltola and colleagues (2000) declared that a higher bending moment is needed to break the stems of trees in frozen conditions (no turn out happened). 
Wind gusts cause different moments compared to pulling tests (which are static). Tree failures were reported at $17.5 \mathrm{~m} / \mathrm{s}$ wind speeds, which were less than the pulling test predicted (James - Kane 2008). (The study of the behavior of groups of trees under windy conditions started as well. Schindler (2008) measured movements of 10 nearby trees during windy conditions and wrote down an analysis of crown interactions.)

Pulling tests can also be used to evaluate trunk conditions at different levels. The pulling happens in the same way while the measurements are done on the trunk, on the stem using elastometers, prisms, accelerometers, or other equipment (Wessolly - Erb 1998; Brudi Wassenaer 2002; Moore et al. 2005; Hagrey 2006; James et al 2013).

The main limitation of the pulling test is its static nature of loading. Wind usually comes in gusts and is dynamic in nature. The pulling test also requires heavy equipment. For an overall evaluation of a tree, a pulling test should be performed in two perpendicular directions, which may not be possible due to the surroundings found in some environments (Brudi - Wassenaer 2002, Sani et al 2012).

In urban areas, the most common usage of a pulling test is to predict the safety of the trees in windy conditions without uprooting the tree or even without decreasing safety. A safety factor calculation used in urban areas is shown in the next section.

\section{SAFETY FACTOR}

Safety factors give us information about tree stability. The simplest definition for safety factor (SF) is given by Equation 1. SF is the ratio of the evaluated capacity and the calculated load (wind, snow, effects of gravity (Gardiner et al. 2000)). SF helps us to evaluate the measurements in the perspective of safety. SF is usually a number or a percent. Regarding trees, safety factors can be established for uprooting, and for trunk breaking.

$$
\mathrm{SF}=\text { capacity of the tree / estimated load }
$$

The estimations presented in this section are the estimations of wind loads for trees (tree surfaces) and load bearing capacities of root systems estimated from pulling tests. The calculations are simplified; however, they have proved their usefulness innumerous field experiences in the work of Wessolly (1991), Brudi and Wassenaer (2002), Divós and his colleagues (2009), Buza and Göncz (2015).

According to the estimations, during the measurements and the calculations, a safety factor for a tree is considered good from 1.5 to $150 \%$. (An assessment of "good" refers to retaining the tree.)

\subsection{Wind load for trees}

Wind is the most common load of trees. As the wind reaches the surface of the crown and the stem, it causes a moment to which the tree should respond. The moment of wind load is estimated by Equation 2.

$$
\mathrm{M}_{\text {wind }}=f \mathrm{c} 1 / 2 \rho \Sigma\left\{\mathrm{u}(\mathrm{z})^{2} \mathrm{~h}(\mathrm{z}) \mathrm{A}(\mathrm{h}(\mathrm{z}))\right\}
$$

where $f$ is the natural frequency factor, $\rho\left[\mathrm{kgm}^{-3}\right]$ denotes the air density, $\mathrm{u}(\mathrm{z})\left[\mathrm{ms}^{-1}\right]$ expresses the wind velocity, $\mathrm{h}(\mathrm{z})[\mathrm{m}]$ is the height of unit-area at a specific position in crown surface, $\mathrm{A}\left[\mathrm{m}^{2}\right]$ is the crown surface at respective height, and $\mathrm{c}$ is the aerodynamic drag factor.

Note that wind speed and air density depend on the geographical and the topographical situation as well as the seasonal and meteorological influences. 


\subsection{Safety factor for the root system for uprooting}

Evaluation of SF for uprooting is based on pulling and uprooting experiments. Force and inclination data are collected during the pulling test. These data should be filtered according to the relaxation of the tree. For the description of the relationship between the applied force and the inclination of the trunk at ground level during uprooting tests, a tangential function proved suitable.

This function can be fitted to the filtered data and shown by Equation 3.

$$
\varphi_{\text {calc }}=0.33 \tan \left(\mathrm{F} / \mathrm{F}_{\text {tip }}\right)+0.5\left(\mathrm{~F} / \mathrm{F}_{\text {tip }}\right)^{2}-0.1\left(\mathrm{~F} / \mathrm{F}_{\text {tip }}\right)
$$

where $\varphi_{\text {calc }}$ is the fitted inclination, $F[N]$ is the measured force and $F_{\text {tip }}[N]$ is the evaluated tipping force. (See the filtered data in Figure 2.)

The moment which could uproot the tree is

$$
\mathrm{M}_{\text {tip }}=\mathrm{F}_{\text {tip }} \mathrm{L} / \cos \alpha
$$

where $\mathrm{L}[\mathrm{m}]$ is the cable's height on the examined tree and $\alpha$ is the cable's degree (Figure 1).

Based on Equation1, the following equation can describe the SF for the root system for uprooting calculated from a pulling test.

$$
\mathrm{SF}_{\text {root }}=\mathrm{M}_{\mathrm{tip}} / \mathrm{M}_{\text {wind }}
$$

The presented calculations are used after pulling tests as well for the evaluation of tree safety along streets, in parks, or in other situations. Advice regarding the retaining or felling of a tree can really help the work of the gardeners.

\section{ACOUSTIC DETECTION OF ROOTS}

Acoustic detection of roots is a technique inspired by other acoustic techniques (time-of-flight measurement, tomography; Grabianowski et al. 2006; Wang 2013) used for tree evaluation. The method has been developed at the University of West Hungary and the new method has been tested in the university's botanical garden (Divós 2008).

The physical background of the measurement is the velocity-difference in wood and soil. The acoustic signal's velocity in soil is about $250-400 \mathrm{~m} / \mathrm{s}$ depending on soil type and moisture content, while the velocity in the roots is between 2000 and $4000 \mathrm{~m} / \mathrm{s}$ (Bucur 1995; Divós et al. 2009).

Based on these differences, models have been constructed to estimate the acoustic signal's path in both pure soil and the soil containing roots. After successful experiments, a set-up for field usage has been designed. The device consists of a transmitter, a receiver, and a timemeasuring component. The transmitter is needle-like and should be placed onto the trunk at ground level, while the receiver is a long metal spike (30 cm or longer), which has a good coupling for the soil(Figure 3) (Divós et al. 2009; Buza - Göncz 2015).

At realization of acoustic detection, a very short signal (an 'acoustic flash') is sent from the transmitter to the tree and to the roots. The time measure turns on. When the receiver detects the arrival of the acoustic signal, the time measure stops. When a root is nearby (closer than 10 $\mathrm{cm}$ ), the travel time decreases significantly. The depth of the root can be estimated as well. This technique can find roots from $4 \mathrm{~cm}$ diameter and can separate two roots from each other if there is at least $20 \mathrm{~cm}$ distance between them (Divós et al. 2009). The maximum depth for detection is $50 \mathrm{~cm}$. 


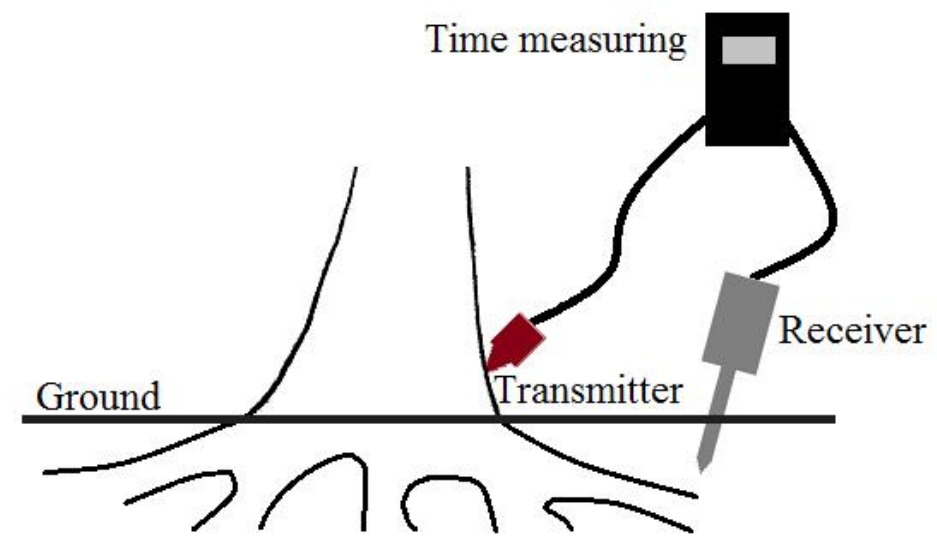

Figure 3.Acoustic root detection needs a transmitter placed on the trunk near to the ground and a receiver which can be stuck into the ground. The transmitter generates an acoustic signal which travels through the wood material. If the receiver is near a root, the traveling time of the signal changes significantly.

The measure is usually performed along a circle around the trunk, with a step of $10-15 \mathrm{~cm}$. The measurement is repeated along wider and wider circles. The direction of the roots can be marked by sand or typed to a program. An example of root detection is seen in Figure 4 and 5. A comparison of predictions of the theoretical model and the measured data were performed; contrasting of evaluated root system and real root situation was completed as well. The roots were excavated and the 3D model of the evaluated root system fit well to the roots found by uncovering.
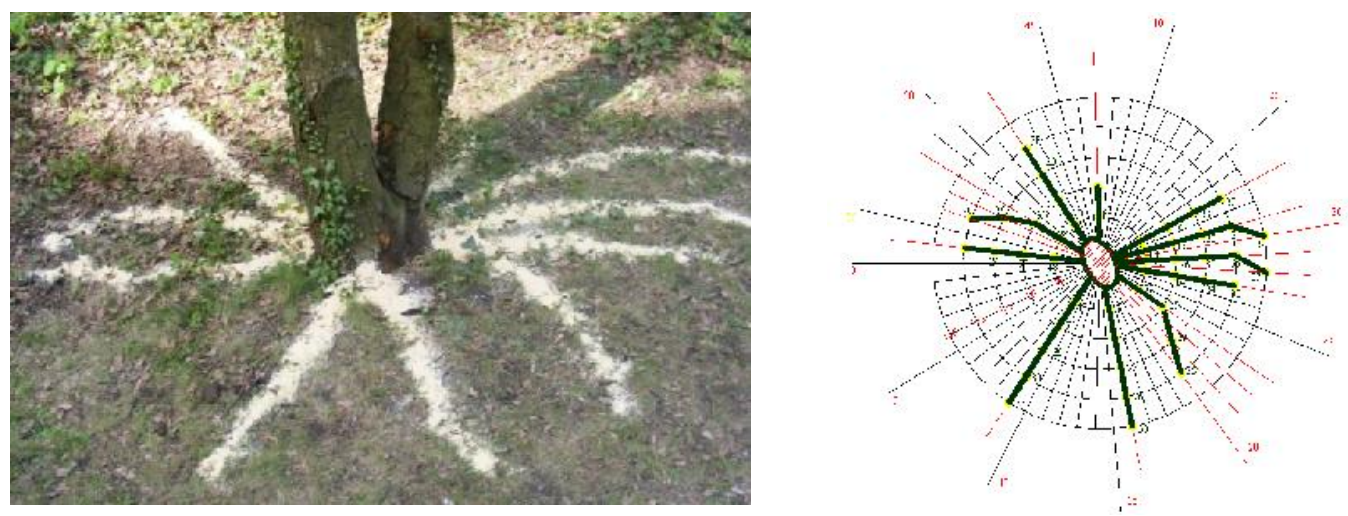

Figure 4. A measured tree in the botanical garden of the University of West Hungary (left) and the root map calculated by the program (right) (Divós 2008)
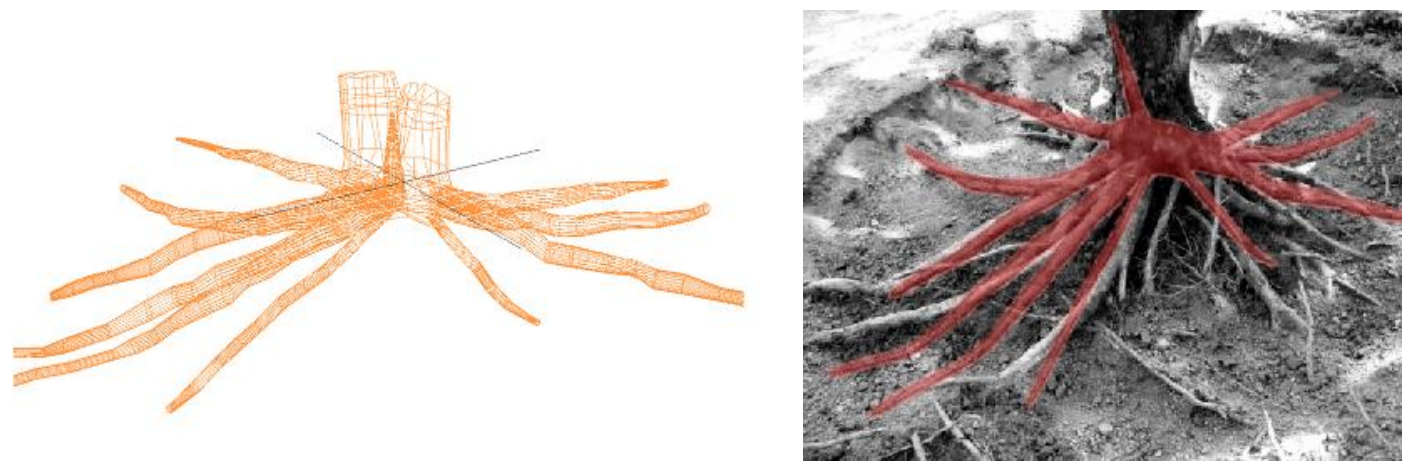

Figure 5. The 3D model of the root system (left) compared to the result of excavation (right) (Divós et al. 2009)

In further measurements, the area reached by the roots was evaluated and compared with 
safety factors from the pulling test. The calculated data were different; however, the results of acoustic root detection seem to be in correlation with the safety factors predicted by the pulling test. For instance, the ratios of the data for two trees were 1.68 from the pulling test and 1.53 from acoustic root detection. This is a difference about $10 \%$; however, the rations are promisingly close (Buza - Göncz 2015).

Limitations of the presented technique are clear; roots with diameters smaller than $4 \mathrm{~cm}$ are not seen by acoustic detection, and the maximum depth of the measure is about $0.5 \mathrm{~m}$. Nevertheless, compared to other available techniques like ground penetration radar (GPR) or electric resistivity tomography (ERT), acoustic root detection has a remarkable advantage; the roots of the measured tree are detected. Signals of GPR and ERT both change in the presence of a root. However, GPR and ERT signals also change even if tubes, rocks, or other materials are buried (Hruska - Cermak 1999; Cermak et al. 2000; Stokes et al. 2002; Hirano et al. 2008).

\section{SUMMARY}

Non-destructive tests can provide quantifiable information about the inner conditions of trees. As the trees are not injured during the tests, repeated measurements and long term monitoring are possible as well. Safety is an important topic as tree failure can cause property damage or harm to humans.

NDT techniques were presented for the evaluation of root system safety; the pulling test was described along with the calculation of safety factors. Acoustic root detection was also presented.

Even though real wind is different from static tests, a pulling test can be used to evaluate the moment the wind load needed to turn out the trees is achieved. Usages, possibilities, and limitations of the pulling test were summarized in this paper.

One of the advantages of acoustic root detection is its ability to find the root of a selected tree, but it can also be utilized as a tool for safety evaluations.

Predicting the conditions of root systems is an area where complex knowledge is needed to get useful results. By collecting information about the mentioned techniques, our aim was to present the work occurring at the University of West Hungary, where the acoustic root detection method was developed, and to help involved researchers understand the available measurements and their limitations.

\section{REFERENCES}

ACHIMA, A. - NiCOLL, B.C. (2009): Modelling the anchorage of shallow-rooted trees. Forestry 82 (3): 273-284.

Amato, M. - Basso, B. - Celano, G. - Bitella, G. - Morelli, G. - Rossi, R. (2008): In situ detection of tree root distribution and biomass by multi electrode resistivity imaging. Tree Physiology 28 : 1441-1448. http://dx.doi.org/10.1093/treephys/28.10.1441

Bell, H.J. - DAwSON, A.R. - BAKER, C.J. - WRIGHT, C.J. (1991): Tree stability. In: Hodge, S.J. (Ed.), Research for Practical Arboriculture. HMSO, London, University of York. 94-101.

Bergeron, C. - RUEL, J.-C. - Elie, J.-G. - Mitchell, S. J. (2009): Root anchorage and stem strength of black spruce (Piceamariana) trees in regular and irregular stands. Forestry 82 (1): 29-41.

Borden, K.A. - ISAAC, M.E. - ThevathasAn, N.V. - GORDON, A.M. - ThOMAS, S.C. (2014): Estimating coarse root biomass with ground penetrating radar in a tree-based intercropping system. Agroforestry Systems 88: 657-669. http://dx.doi.org/10.1007/s10457-014-9722-5

BRUDI, E. - VAN WASSENAER, P.J. (2002): Trees and Statics: Nondestructive Failure Analysis. In: Tree 
Structure and Mechanics Conference Proceedings: How Trees Stand Up and Fall Down. International Society of Arboriculture, Champaign, Illinois. 53-70.

BUCUR, V. (1995): Acoustics of Wood. CRC Press. 1995298 p. ISBN-10: 0849348013

BUZA, A.K. - GÖNCZ, B. (2015): Comparison of trees and NDT methods. Wood Research 60 (1): 45-58.

Cermak, J. - Hruska, J. - MARTinkova, M. - PraX, A. (2000): Urban tree root systems and their survival near houses analyzed using ground penetrating radar and sap flow techniques. Plant and Soil 219: 103-116. http://dx.doi.org/10.1023/A:1004736310417

Clair, B. - Fournier, M. - Prevost, M.F. - BeAuchene, J. - BARbet, S. (2003): Biomechanics of buttressed trees: bending strains and stresses. American Journal of Botany 90 (9): 1349-1356.

CouTTS, M.P.(1983): Root architecture and tree stability.Plant and soil 71: 171.

DANJON, F. - REUBENS, B. (2007): Assessing and analyzing 3D architecture of woody root systems, a review of methods and applications in tree and soil stability, resource acquisition and allocation. Plant and Soil 303: 1-34. http://dx.doi.org/10.1007/s11104-007-9470-7

DIvós, F. (2008): Acoustic evaluation of tree's root system for evaluation of stability (Available in Hungarian: "Fák gyökérzetének akusztikus vizsgálata a stabilitás meghatározásához."). Report for "Acoustic examinations of roots of trees" FAGYOKER, NKTH (Baross)-06 tender2007.07.02.2008.06.30. 19 p.

Divós, F. - BEJO, L. -TOTH, A. (2009): Instrument supported tree evaluation in Hungary. In: Zhang H., Wang X. (ed) Proceedings of the 16th International Symposium on Nondestructive Testing of Wood. Beijing Forestry University, Beijing, China. 71-76.

DORREN, L.K.A. - BERGER, F. (2005): Stem breakage of trees and energy dissipation during rockfall impacts. Tree Physiology 26: 63-71. http://dx.doi.org/10.1093/treephys/26.1.63

Gardiner, B. - Peltola, H. - Kellomaki, S. (2000): Comparison of two models for predicting the critical wind speeds required to damage coniferous trees. Ecological Modelling 129: 1-23.

GRABIANOWSKI, M. - MANLEY, B. - WALKER, J.C.F. (2006): Acoustic measurements on standing trees, logs and green lumber. Wood Science and Technology 40: 205-216. http://dx.doi.org/10.1007/s00226-005-0038-5

GuO, L. - CHEN, J. - CUI, X. - FAN, B. - LIN, H. (2013): Application of ground penetrating radar for coarse root detection and quantification: a review. Plant and Soil 362: 1-23. http://dx.doi.org/10.1007/s11104-012-1455-5

HAGREY, AL S.A. (2006): Geophysical imaging of root-zone, trunk, and moisture heterogeneity. Journal of Experimental Botany 58: 839-854. http://dx.doi.org/10.1093/jxb/erl237

HiRANO, Y. - DANNOURA, M. - AONO, K. - IgARASHI, T. - ISHII, M. - YAMASE, K. - MAKITA, N. KANAZAWA, Y. (2008): Limiting factors in the detection of tree roots using ground-penetrating radar. Plant and Soil 319: 15-24. http://dx.doi.org/10.1007/s11104-008-9845-4

HRUSKA, J. - CERMAK, J. - SUSTEK, S. (1999): Mapping tree root systems with ground-penetrating radar. Tree Physiology 19: 125-130. http://dx.doi.org/10:1093/treephs/19.2.125

JAMES, K.R. - KANE, B. (2008): Precision digital instruments to measure dynamic wind loads on trees during storms. Agricultural and Forest Meteorology 148: 1055-1061. http://dx.doi.org/10.1016/j.agrformet.2008.02.003

JAMES, K. - HALlAM, C. - SPENCER, C. (2013): Measuring tilt of tree structural root zones under static and wind loading. Agricultural and Forest Meteorology 168: 160-167. http://dx.doi.org/10.1016/j.agrformet.2012.09.009

KANE, B. - Clouston, P. (2008): Tree pulling tests of large shade trees in the genus Acer. Arboriculture and Urban Forestry 34 (2): 101-109.

LUNDSTRÖM, T. - JONAS, T. - STÖCKLI, V. - AMMANN W. (2007A): Anchorage of mature conifers: resistive turning moment, root-soil plate geometry and root growth orientation. Tree Physiology 27: 1217-1227. http://dx.doi.org/10.1093/treephys/27.9.1217

LunDSTRÖM, T. - JONAS, T. - KALBERER, M. (2007B): The root-soil system of Norway spruce subjected to turning moment: resistance as a function of rotation. Plant Soil 300:35-49 http://dx.doi.org/10.1007/s11104-007-9386-2

Moore, J.R. (2000): Differences in maximum resistive bending moments of Pinus radiata trees grown on a range of soil types. For. Ecol. Man. 135: 63-71. 
MoORE, J.R. - GARDiner, B.A. - BLACKBURN, G.R.A. - BRICKMAN, A. - MAGUiRE, D.A. (2005): An inexpensive instrument to measure the dynamic response of standing trees to wind loading. Agricultural and Forest Meteorology 132: 78-83. http://dx.doi.org/10.1016/ j.agrformet.2005.07.007

Morelli, G.F. - Zenone, T. - TeObAldelli, M. - Fischanger, F. - Matteucci, M. - Seufert, G. (2007): Use of ground-penetrating radar (GPR) and electrical resistivity tomography (ERT) to study tree roots volume in pine forest and poplar plantation. In: Proceedings of the 5th International Workshop on Functional-Structural Plant Models p. 21-1 21-4.

NEILD, S.A. - WoOD, C.J. (1999): Estimation stem and root-anchorage flexibility in trees. Tree Physiology 19: 141-151. http://dx.doi.org/10.1093/treephys/19.3.141

Peltola, H. - Kellomaki, S. - Hassinen, A. - Granander, M. (2000): Mechanical stability of Scots pine, Norway spruce and birch: an analysis of tree-pulling experiments in Finland. Forest Ecology and Management 135: 143-153. http://dx.doi.org/ 10.1016/S0378-1127(00)00306-6

RAHARDJO, H. - HARNASA, F.R. - INDRAWANA, I.G.B. - LEONGA, E.C. - TANB, P.Y. - FONGC, Y.K. OwC, L.F. (2014): Understanding the stability of Samaneasaman trees through tree pulling, analytical calculations and numerical models. Urban Forestry and Urban Greening 13: 355-364. http://dx.doi.org/10.1016/j.ufug.2013.12.002

RAY, D. - NiCOLL B.C. (1998): The effect of soil water-table depth on root-plate development and stability of Sitka spruce. Forestry 71 (2): 169-182.

Rodgers, M. - CASEY, A. - MCMENAmin, C. - Hendrick, E. (1995): An experimental investigation of the effects of dynamic loading on coniferous trees planted on wet mineral soils. In: Coutts, M.P., Grace, J. (Eds.), Wind and Trees. Cambridge University Press. 204-219.

SANI, L. - LISCI, R. - MOSCHI, M. - SARRI, D. - RIMEDIOTTI, M. - VIERI, M. (2012): Preliminary experiments and verification of controlled pulling tests for tree stability assessments in Mediterranean urban areas. Biosystems Engineering, 112 (3): 218-226.

SCHINDLER, D.(2008): Responses of Scots pine trees to dynamic wind loading. Agricultural and forest meteorology 148: 1733-1742.

SIEGERT, B. (2013): Comparative Analysis of Tools and Methods for the Evaluation of Tree Stability Results of a field test in Germany. Arborist•News april: 26-31.

SILINS, U. - LIEFFERS, V.J. - BACH, L. (2000): The effect of temperature on mechanical properties of standing lodgepole pine trees. Trees 14 (8): 424-428.

Stokes, A. - Fourcaud, T. - Hruska, J. - Cermak, J. - Nadyezhdin, N. - Praus, L. (2002): An evaluation of different methods to investigate root system architecture of urban trees in situ: I. Ground penetrating radar. Journal of Arboriculture 28 (1): 2-10.

WANG, X. (2013): Acoustic measurements on trees and logs: a review and analysis. Wood Science and Technology 47: 965-975. http://dx.doi.org/10.1007/s00226-013-0552-9

WANG, X. - Ross, R.J. - CARTER, P. (2006): Acoustic evaluation of wood quality in standing treesPart I. Acoustic wave behavior. Wood and Fiber Science 39: 28-38. .

WeSSOlLy, L. - ERB, M. (1998): Handbuch der Baumstatik und Baumkontrolle. Patzer Verlag, Berlin, Germany. 1998270 p. ISBN 3-8761-093-1

Wessolly, L. (1991): Verfahren zur Bestimmung der Stand- und Bruchsicherheit von Baumen. HolzalsRoh- und Werkstoff 49: 99-104.

Wu, Y. - GuO, L. - CUI, X. - CHEN, J. - CAO, X. - LIN, H. (2014): Ground-penetrating radar-based automatic reconstruction of three-dimensional coarse root system architecture. Plant and Soil 383: 155-172. http://dx.doi.org/10.1007/s11104-014-2139-0

Zenone, T. - Morelli, G. - Teobaldelli, M. - Fischanger, F. - MATteucci, M. - Sordini, M. ARMANI, A. - FERRE, C. - ChITI, T. - SEUFERT, G. (2008): Preliminary use of ground-penetrating radar and electrical resistivity tomography to study tree roots in pine forests and poplar plantations. Functional Plant Biology 35: 1047-1058. http://dx.doi.org/10.1071/fp08062 